\title{
EKILA: BLOOD, BODIES AND EGALITARIAN SOCIETIES
}

\author{
Jerome Lewis \\ University College London
}

\begin{abstract}
Mbendjele forest hunter-gatherers in Northern Congo refer to a confusing body of seemingly unconnected and diverse practices and beliefs as 'ekila'. Ethnographically ekila has many meanings. I suggest a number of possible ways to understand what connects these different practices, but argue that it is only when considering learning in this egalitarian environment that ekila really begins to make sense. The ethnography demonstrates how formulaic and counter-intuitive explanations of specific taboos and related behaviour stimulate a learner-motivated pedagogic process which does not depend on defining any individual or institution as a focus for Mbendjele to learn important knowledge. Ekila anchors key areas of cosmological knowledge, gender and political ideology in the physical and biological experiences of human growth and maturation so that gendered practices and cultural values take on a natural, inevitable quality.
\end{abstract}




\section{Introduction}

Although similar practices to those called ekila by the Mbendjele are common among linguistically diverse groups of Pygmy hunter-gatherers in Congo-Brazzaville, Central African Republic, Eastern Cameroon, Gabon and Eastern Democratic Republic of Congo $(\mathrm{DRC})^{1}$, ekila or corresponding concepts have scarcely been discussed in the ethnographic literature on these people ${ }^{2}$. Similar concepts, most frequently discussed in terms of rules concerning hunting, eating, sex and menstruation are ubiquitous among hunter-gatherers and common in societies throughout the world ${ }^{3}$. My discussion of these practices among the Mbendjele proposes an analysis that examines ekila from the point of view of people’s movement through life and the way physique and understanding grow together.

Without formal institutions for accepting or rejecting innovations, without school-like institutions or authorities for standardising knowledge, where it is rude to ask questions, or to comment on others, it seems surprising that a concept such as ekila be distributed so widely among hunter-gatherers in Central Africa. Brunton (1989) has argued that cultural continuity in egalitarian societies, such as those discussed here, is fortuitous. I shall explain why this is a mistaken assumption, and describe certain aspects of cultural reproduction in this context. As Jackson has remarked (1983: 339), in pre-literate societies indigenous understandings are frequently embedded in practices (doings) rather than spelled out in ideas (sayings). I argue that certain key meanings and moral sentiments can be durably and effectively transmitted tacitly because they are embedded in inevitable sensory experiences connected with bodily maturation and performance rather than conveyed just by instruction and verbal exhortation. 


\section{What people say about ekila}

In speech ekila can refer to menstruation, blood, taboo, a hunter's meat, animals’ power to harm humans, and particular dangers to human reproduction, production, health, and sanity. Since this polysemy makes any single word translation of ekila problematic, I use the Mbendjele term rather than an English one.

People rarely talk about ekila directly, especially not as an abstraction or specific body of practices. Ekila proscriptions are normally only discussed spontaneously in real situations when they are not being followed, or in an effort to explain misfortune. Nevertheless, ekila practices are ubiquitous. Thus I was hardly aware that some of my first fieldnotes concerned ekila practices. When sharing meat I noted that certain portions were always given to the hunter and other portions to the men's group; or that a new mother whose baby had a hooting cough blamed the cough on her having eaten, while pregnant, a black and white colobus monkey (the monkey has a bark-like hooting call); or when a hunter refused to eat a sitatunga antelope he had killed, despite his own hunger, saying he had young children.

The connections between these different events were unclear to me until around eighteen months had passed and my improved language skills made me more sensitive to the networks ekila implies. The slow process of recognising its significance seems to me a key characteristic of ekila. It gives learning about ekila the character of personal revelation, rather than piecemeal understanding. Observing this happening in myself has been partly responsible for the direction my analysis has taken. 
One occasion was particularly significant in alerting me to the importance of ekila. As I sat in sixty-five year-old Phata's leaf hut, situated in forest teeming with large game, he pointed to his sleeping mat.

'This is where I sleep, all alone. Just me, without any women, by myself on this mat! I don’t sleep with my wife anymore because of ekila. My ekila is big, very big! I kill elephants ‘baaaaaam’! Old men, kombeti like me, don’t screw women any more because of ekila. That's how the fathers advised us to look after our ekila.

'Ekila is something only for one person... If you mix your ekila around with lots of people then, if you're a man, your hunting is ruined (matena). A woman has problems in childbirth ( $\varepsilon k o n d i)$, and her infants get weak and ill. Children who can walk can do as they like, they have their own ekila.

'After your wife has given birth, it is ekila to have sex with her until the child can walk. Otherwise you can kill the child...

JL: Do women have ekila?

‘Women have ekila too. A woman's ekila is with the moon. When a woman is ekila [menstruating] her husband takes her smell. So he doesn't go hunting or walking in the forest with friends. Animals flee when they smell a woman's mobcku. The animals smell her on him. If strong animals, like gorillas, elephants, buffalo, or leopards, smell it they will come, even from far away, charging towards him in a rage, passing other people by just to get him ${ }^{4}$.' 
Phata, 65 year-old kombeti from Ibamba, March 1997.

I followed up this conversation with further interviews, such as this one with Emeka.

'Ekila is the same as mobsku. That's the name of the medicine God (Komba) sent women when women put in the moon [menstruate]. The business of ekila was first with them. It is all about children. You can see women's tummies swell up at this time. It's the wind. They have to expel their wind as ekila [blood]; this cleans out their wombs... If she doesn’t do ekila, then she has to do ekila... Women’s biggest husband is the moon.

'If I'm a hunter, I don’t sleep around with different women. If I slept with her, then her, and then her, all the animals would know. They would smell my smell and know "that hunter has ruined his own ekila [ruined his hunting]". Some will come with great anger. Others, you shoot them, but they won’t die. You are very surprised. When you shoot at an antelope from close range and it doesn’t die, we call this ekila ...

JL: Does a good hunter have strong ekila?

'If someone’s hunting (moengi) is good, they won’t say his ekila is strong. They will say “he hasn’t ruined his ekila”. Even a great hunter who sleeps around with women all over the place will ruin his hunting. We call a man who’s ruined his hunting with women "matena”. 


\section{JL: Why do you call all this ekila?}

'We Yaka call all this ekila because our fathers called it that. This whole business comes from our forebears. Women's blood is one thing, men killing animals is another. Komba made it like this. When women put in the moon, it is mobsku. Men's mobeku is a nose-bleed. Men's ekila is about hunting. The hunter's meat is ekila. If someone else eats your ekila meat, your hunting is ruined.

'Animals have ekila. They caused suffering to our fathers: buffalo, bongo antelope, black-fronted duiker [all are red animals] and sitatunga - but only the red coloured females, not the dark-coated ones. They thought that the red sitatunga looked like a bongo antelope... The bongo has a huge and dangerous ekila.'

Emeka, 48 year-old Mbendjele man from Ibamba, June 1997.

These conversations bring out some of the domains covered by ekila, but are by no means exhaustive. For instance, as among the Batek Negritos (Endicott 1979: 74) and Penan (Needham 1967), it is ekila to burn leeches. Human blood-sucking parasites; chiggers, ticks, fleas, mosquitoes, tsetse flies, etc. when swatted or removed must never be disposed of in a fire. The smoke emitted makes people ill, especially if it is a fire for preparing food. Some people can go mad.

Even a partial understanding of ekila begins to suggest explanations for key areas of cultural practice; such as the gendered nature of production or relations between humans and animals. Ekila defines how the body's vital forces, reproductive potential, productive activities and their products, moral and personal qualities, and emotions should be shared 
so as to ensure that group members experience good health, unproblematic child-birth and child rearing, and successful hunting and gathering. From an Mbendjele perspective these are the basic components of a good life.

Yet, ekila is ambivalent. If it is not 'ruined' ekila is positively valued, but it can have negative consequences if not treated properly. Mobsku is ambiguous too, but simply put seems to refer to an incident (such as a nose-bleed) that, if not properly handled, can result in danger and suffering to humans, or is taken as a sign that ekila has been ruined and certain valued activities should be avoided.

The resemblance of these formulations about ekila to similar ideas found amongst other hunter-gatherers is remarkable. To illustrate this point I shall briefly describe similar beliefs and practices among the San of Southern Africa, though other groups could have been used. Bleek and Lloyd also describe much that appears to connect the /Xam moon with menstruating women. Biesele (1993: 93) describes how the Ju/'hoansi also connect women's cycles and the moon, for instance in their expressions for menstruation, ho n! ui (to see the moon) and $u$ a n! ui khoea (go to the moon) $)^{5}$. Lorna Marshall reported that the Ju/'hoansi tell of men killed by elephants for failing to observe menstrual taboos; that a man whose wife is menstruating should not go hunting for fear of attack by carnivores and for fear the game will escape (Biesele 1993: 92). Bleek and Lloyd (1968: 77-79) recorded a /Xam story about a menstruating girl in which she 'cools' the 'hot' and effective bows, arrows and hands of young male hunters. Are these similarities simply seductive ways of explaining misfortune? 
Using ekila to explain why I missed that antelope or was the one attacked by an elephant might be likened to a discourse on luck. But ekila is quite different from widespread Bantu beliefs common among many of the Mbendjele’s farming neighbours concerning luck and destiny. As Fortes (1981) so clearly explained for the Tallensi of Ghana, luck indicates whether one's ancestrally preordained destiny is good or bad. Bad luck implies a bad destiny. This can only be remedied through the mediation of elder male relatives (living and dead) and diviner-informed sacrifices to their ancestors.

The dependency on elder male relatives in the Tallensi-style ancestor cults is very similar to ancestor cults that flourish among many of the Mbendjele’s villager neighbours. Such dependency serves to uphold a patriarchal political system dominated by elder men. By contrast, the egalitarian Mbendjele do not have an equivalent concept of 'luck', nor of judgemental ancestors. Remedies to ekila problems are performed by the individual affected, possibly with the assistance of a specialist of their choosing.

For Mbendjele, success in crucial life activities should be straightforward because the forest is perceived as abundant in resources and generous in dispensing them. Similar views of the environment among forest hunter-gatherers were used by Bird-David in her formulation of the Nayaka's, and others', view of the forest 'as parent', giving generously to its children (1990). In Tallensi terms this translates as all creatures sharing a good destiny.

Mbendjele expect life to go well, but of course it often does not. Macongo, normally an excellent hunter, came back to camp on two successive days having missed his prey. Other men commented 'It must be your ekila'. He responded forcefully that he had 
simply missed and it had nothing to do with ekila. Mbendjele apply a good deal of common sense to explain situations, but when problems repeat themselves or are otherwise difficult to explain people may have recourse to notions such as ekila. So, another skilled hunter, Benasongo, who was frequently attacked by gorillas when he went hunting, was clear that his ekila had been ruined by other men’s jealousy of his success (Lewis 2002: 99, 2003). In rationalising unusual problems, ekila rules frequently define how people should conduct their relationships with each other and with animals.

\section{Structuring human-animal and human-human relations}

Much of Mbendjele life is spent interacting with animals or their carcasses. Numerous ekila practices, particularly the more visible ones, concern how people should manage their relations with animals, and hence also with one another. Since people kill animals to eat them many rules implicate gendered production and human reproduction. A description of some of the most obvious ekila rules illustrates this.

A hunter's success demonstrates that his ekila has not been ruined. To maintain his success he and his wife should observe all ekila proscriptions, whether concerned with how they share his production, what they eat or who they have sex with. To maintain his ekila the hunter who first struck the slain animal ${ }^{6}$ must eat certain cuts of the meat with his children, father and wife. This meat is simply referred to as ekila. Eating it will ensure that he finds game easily, that his aim is true and that he makes a quick kill when next hunting ${ }^{7}$. If others, such as his own mother, parents-in-law, or potential sexual partners other than his wife, eat his ekila meat, his hunting is ruined. 
Piko meat must be removed from each animal killed for immediate roasting and consumption by the men present. Piko meat is normally composed of certain internal organs, often the liver, kidneys and stomach and sometimes ribs. A hunter failing to provide piko meat ruins his ekila. The rest of the meat is publicly shared among all present. If it is not, his ekila will also be ruined. Except in unusual circumstances, such as when he is the only man in camp, the hunter will not butcher and share out his kill. Other men do this. Ideally they take the carcass from the hunter as soon as they see him and proceed to butcher and share out the meat according to ekila rules and equitable sharing. These practices emphasise that the hunter's success is tied to the appropriate sharing of his production and his sexuality.

\section{Why are certain animals ekila and not others?}

As Emeka explained earlier, certain animals, such as the Bongo antelope, have a 'big ekila' (ekila abole). These animals pose a direct threat to human reproduction and are carefully avoided by adults involved in reproduction. However, children and postmenopausal couples can eat these animals, so hunters sometimes kill them. Although those I asked agreed with the core list of ekila animals mentioned earlier by Emeka, many had other animals they considered ekila too. ${ }^{8}$

'If you eat a black-fronted duiker, it kills your child. You will say "My children are being killed by sorcery”... but it's actually that black-fronted duiker you ate. It's the same with blue duiker. You must never eat his belly $(g u n d u)^{9}$. If you do your child will get terrible diarrhoea. We people from Ibamba, we ate blue duiker. Before it was nothing, it didn't do anything to us. We killed many in our hunting nets and everyone would eat them. But now we think blue duiker is ekila. 
'The Yaka from below [Luma Pygmies] gave us this business about blue duikers. Their healers explained the mobsku of blue duikers... When we heard about this, we did the same.' Emeka, 48 year-old Mbendjele man from Ibamba, June 1997.

Ekila practices are not static. The inclusion of blue duiker into the core group of ekila animals is slowly spreading northwards as groups meet each other and explain the ekila of blue duikers. If a pregnant woman or her husband eat blue duiker this could cause the foetus to turn its head up and backwards, like a frightened blue duiker looking backwards as it flees. This would make birth difficult and dangerous. Given that the ubiquitous and delicious blue duiker is so often hunted, the speed with which this taboo is spreading surprises me.

The ability to absorb new practices, and probably forget old ones, while integrating the new into the same ideological and moral super-structure, is part of the enduring strength of ekila. Such flexibility makes ekila a seductive explanation for misfortune. Indeed, each family I asked had a slightly different list of ekila animals. People told me they followed their parents' prohibitions and would add any animals that had caused them problems.

So, although many of the animals people avoid are not red-coloured, the minimum list of ekila animals, those Emeka described as coming from the forefathers, is composed of red animals. To what extent can colour symbolism explain this? Although sharing the same colour as blood, this link was never made explicit by my informants. Like numerous Central African people, the Mbendjele have three colour terms, mopindo (black), motele (red) and pumbu (white). Mbendjele have not elaborated these distinctions to me very 
much, and colour metaphors are not used to organise special areas of esoteric knowledge as Turner describes in Ndembu initiation teachings (1967).

In contrast to the Nyuswa-Zulu (Ngubane 1977) Mbendjele do not code black and white as good or bad, or indeed as a dichotomy, or in a triad with red. Rather they tend to use them descriptively. Elderly Doka told me that when she meets dead relatives in dreams they look white. When someone dies, their relatives disguise themselves by painting themselves white so as to appear as spirits to the deceased. This will stop the deceased feeling jealous of them for remaining alive. Mbendjele say that white people have returned from the land of the dead - Europe. Indeed, a common euphemism for saying someone has died is to say they have gone to Europe 'amu dua putu' ' Although white is associated with the dead and spirits this is descriptive. Black is little symbolically elaborated.

Red is symbolically elaborated by its use to mark people at particularly potent or vulnerable moments. For example, mongole, a red paste made from scraping dried bark of Pterocarpus soyauxii, ${ }^{11}$ is the preferred base to which herbal remedies are added before being administered. Very ill people or people undertaking mystical activities often have their body painted red using mongole. This action was said to make them strong. Newborn babies are smeared red with mongole paste after each bath in order to make them 'grow well'. The young Ejengi neophyte is smeared with mongole paste by his mother and aunts on the day of his potentially deadly ordeals. They do this to make him strong, and beautiful. 
The frequent use of red to mark people in potent, dangerous or vulnerable situations may be why red animals seem obviously pre-occupying to Mbendjele. The other animals appear to be opportunistic entrants into the ekila category, often included as a means to explain specific misfortune. The use of red to mark potency could be based on the observation of ripening fruit, or that women are marked red by blood when most reproductively potent.

\section{Ekila and human reproduction}

Although elders and children readily consume most animals, I observed that as Mbendjele youths approach late puberty they begin to respect ekila food taboos. The link between sexual awareness and awareness of ekila proscriptions is not accidental. Animals react strongly to human ekila, particularly menstruation, following sexual intercourse, for the duration of a pregnancy, and while suckling a small infant. Couples involved in such activities are mobsku.

'If you are mobsku animals attack you. In big forest full of large game, having sex is mobsku - a huge ekila. This is because we are in conflict (bita) with the animals. If they smell the odour of women, some are frightened and flee you. Others come from far away and follow you, only you. That's why women are frightened in the forest. The animals smell them.'

Kabelo, 28-year-old man from Ibamba, January 1997.

Human ekila is especially offensive to animals at high points in human reproductive potency. Intentional violence between humans and animals occurs in both directions. The implication of Kabelo's statement is that when people are mobcku they are in the process 
of making new humans and therefore particularly offensive to animals. When a woman menstruates, she and her husband remain around camp.

Menstruation, owing to its odour, is the most dangerous time for humans in relation to fierce forest animals. Menstruation is not polluting or said to make other people weak. It is positively valued as a necessary and desirable event. Indeed, a woman is considered most fertile during menstruation. Sexual intercourse at this time is said to ensure pregnancy begins. Menstrual blood signifies maximum potency human fertility. This could be why its smell so angers or frightens animals.

A man whose wife is pregnant should not go hunting. He is vulnerable to attack and other animals will flee. On a number of occasions after tracking game for some time, we lost the prey. I was surprised when this was blamed on one of the party having a pregnant wife, despite more 'straight forward' reasons, such as the strong black tobacco elders smoke or the noise we made. Men whose wives are pregnant should remain at camp doing odd jobs and looking after everyone else’s children. Since pregnancy lasts for so long men tend to ignore this injunction from time to time.

'Children come out of men, the liquid of men. A child is only sperm. You put your sperm into the body of a woman. You do this every day, every day until her moon is dead. Who saw her moon? So she asks you, her husband, “Where’s the moon? He didn't come up this month.

'We men cut the moon from women [said with laughter]. If your wife puts in the moon, you her husband must cut her moon. If you do this, a child will start growing 
in her womb... Their big secret is making children from our sperm. Our work is to give body to the child; the woman's to give birth to it.'

Kabelo, 28-year-old man with two wives, from Ibamba. January $1997^{12}$

Mbendjele emphasise that pregnancy is a process requiring continuous 'work' from both husband and wife. Conception is, from this perspective, not a single event. Repeated acts of intercourse ensure that semen is regularly deposited in the womb and link the couple's ekila together in maintaining the pregnancy. Understanding this explains why ekila prohibitions are imposed on the pregnant couple.

As Robertson (1996: 602) observed in his analysis of obuko among the Ganda in Uganda, abstracting concepts from the social relations of production as they develop through time obliterates the way they dynamically unfold into diverse areas of practice and ideology. Beliefs about who should not eat particular foods lead into areas as diverse as folk biology, sexual morals, definitions of correct sharing and theories about human-animal relations.

Ekila illustrates how ideology and practice influence each other in profound ways. So, for instance, although most animals flee humans involved in procreation, certain animals become furious and attack people who smell of human ekila. These are animals, such as gorillas, elephants, buffalo, leopards and poisonous snakes that do attack and sometimes kill people. Pre-menopausal women fear these animals because they smell of ekila from their vaginas. This has important consequences on gender roles and comportment. 


\section{Naturalising gendered relations of production}

Women's fear of attack encourages them to do daily activities in noisy groups. They gather in groups, fish and collect nuts, yams and fruit together and rarely spend time alone. This communalism in daily life establishes strong solidarity between them that has important implications for women's status. It is often used effectively to influence camp decisions. If women refuse a proposition made by men, men can only persuade them, never coerce them. Women quickly support each other in situations of conflict with men, especially in situations of serious domestic violence. During such episodes women often ganged-up to beat a violent husband with long sticks.

Ekila practices and associated explanations contribute crucially to ensuring Mbendjele men and women use their bodies in very different ways and cultivate distinct styles of behaviour. These are exemplified in the way they talk and walk in the forest. Whereas men walk quietly in small groups or alone, women walk in large groups, and talk or yodel loudly to ensure they do not surprise animals. Women’s song-like speech style, and even some vocabulary, is markedly different from men’s. Women accompany each other's speech with sung sounds or idiophones and expletives that contribute to increasing the volume and distinctive tunefulness of their conversations. Men will mostly talk in turn and, although tunefully responding to what is said, do this in a subdued manner by comparison to women. Male valuation of quietness is clear in their common use of signlanguage, especially when hunting, but also in general conversations (Lewis forthcoming).

Since a careful man will not smell of ekila he can sneak up on animals without giving himself away. So, men orientate themselves in their activities towards potentially 
dangerous outsiders such as wild animals, other Mbendjele groups and Bilo villagers. Men describe themselves as warriors, fearlessly hunting large, dangerous mammals, facing fierce bees high up great trees, or obtaining goods from unpredictably dangerous Bilo villagers.

Women orientate themselves inwards in their activities. These are focused on their families, immediate Mbendjele relatives and other camp members. Women often talk fearfully and suspiciously about other groups from different places, loudly retelling outlandish rumours about their bad eating habits or malevolent intentions. Mbendjele women tend to be culturally conservative. They are more reluctant than men to use or try new goods or foods from outside the forest. They often vociferously oppose visits to unknown villages or exotic places such as towns.

Men and women eat separately and people mostly sit around in gender groups when socialising. Although couples may go out on romantic foraging trips, most activities during the day are undertaken in single sex groups. Neighbouring villagers observed to me that Mbendjele have two different societies, one for men and one for women. Indeed, according to the Mbendjele origin myth, they once did (Lewis 2002: 173-7). Women lived from fishing and collecting wild yams without men. The men lived by hunting and collecting honey. The gendered work roles in this myth are the actual work roles of men and women in the forest today. Their daily spatial separation into gendered groups and spaces reinforces the political significance of their mythical autonomy.

Basic beliefs about ekila and the piecemeal explanations given for them differentiate people according to gender, and to a lesser extent, according to age. These distinctions 
have numerous implications for every individual, defining which animals they can eat; whether they will hunt (men) or cook forest animals (women); whether their style of speech in the forest is loud and song-like or quiet and restrained; and whether they walk alone or in groups. Bodily events are culturally elaborated to become clearly expressed differences between the sexes and a gender ideology that defines appropriate activities and behaviour.

Although ekila is mostly discussed in a practical idiom, its consequences are ideological. Breach of rules surrounding ekila causes practical problems, such as unsuccessful hunting or difficult childbirth, while the gendered nature of proscriptions and their consequences make gender roles seem logical and natural. The bodily practices, discipline and behaviour that ekila proscriptions demand serve to justify the key cultural distinctions between what is seen as proper and natural for men and women to do - between obtaining vitality from outside the group versus transforming vitality into new human life within the group.

\section{Ekila's implicit pedagogic action}

Ekila rules of behaviour exert an anonymous but pervasive pedagogic action that prompts each Mbendjele person to learn key cultural knowledge. This teaching occurs neither through an explicit pedagogic institution nor through specialised individuals. Rather, it occurs through the experience of a series of bodily practices and proscriptions and the curiosity these provoke. Bourdieu (1977) emphasised the inculcation of inequality and hierarchy when suggesting that if culture was embodied in such ways it was almost beyond the grasp of consciousness. By passing from practice to practice without 
becoming explicit discourse, habitus remains unchallenged. Ekila is an example of similar processes inculcating egalitarianism.

Menstruation is the ultimate mnemonic for ekila, expanding the individual's awareness outwards into diverse but related areas. The consequences of a Mbendjele girl's first menstruation and subsequent menses thereafter provoke her, and her male relatives, to explore and learn about otherwise obscure areas of knowledge and ideology. The repetition of menstruation over many years provides numerous promptings to continue this exploration. Implicit in the special actions required of her and the men around her when she menstruates are networks of relations that slowly reveal themselves over many years as they unfold into diverse dimensions of cultural practice and ideology. These networks occasionally find verbal expression in formulaic and counter-intuitive explanations of specific taboos and related striking behaviour. The counter-intuitive qualities of these explanations provoke further curiosity and questioning.

Ekila is like a stream running through many areas of Mbendjele practice. Occasionally stepping-stones show through the water, emerging as formulaic explanations for specific practices that lead thought in particular directions. These guide individuals in their personal journey through life, constructing knowledge and understanding as their experience unfolds in an active process of interrogation, speculation and efforts to resolve inconsistencies between experience and knowledge (Robertson 1996: 599).

The natural curiosity ekila provokes educates Mbendjele about key values and practices, folk biology, gender and work roles. But the inclination to enquire about ekila is unevenly distributed, as it is among the anthropologists who have worked amongst them 
and similar peoples. In Farnell’s terms, ekila is a resource for conceptualising appropriate action according to context and purpose (2000: 412). This helps to emphasise that ekila practices and beliefs are not enacted or followed by all, but that people chose to follow, ignore or transgress them according to the context they find themselves in.

Some informants just accepted the proscriptions without questioning them. Others, such as a handicapped man who could not hunt, hardly bothered about them unless something was seriously wrong. Those who were naturally curious gained a broad knowledge of the prohibitions and the various ways of resolving the problems associated with them, and understood more about the linkages between different ekila practices. These tended to be older people. Their more fluent explanations have informed much of this article.

This selection is justified if Robertson's view that meaning is ontogenetic (1996), and Bloch’s study of specialisation, are taken seriously. Bloch (1998: 10) described expertise as not just the ability to remember many instances of certain types of information, but as a process of constructing cognitive mechanisms to organise this information in particularly efficient ways. This process may also be evident in relation to subjects such as ekila that are rarely made explicit.

Time has helped me better understand ekila, as is obvious when comparing my initial thesis chapter (Lewis 2002: 103-120) with my presentation here. Of course I depended on informants who were best able to explain it to me coherently, but also talking and writing about it has helped me to clarify and organise the information. Since understanding is not simply a product of accumulating knowledge, but also of consolidating it and organising 
it in meaningful ways, it is no surprise that older, more experienced people are often more attractive informants to anthropologists. I am no exception.

But, as Robertson cautions, anthropologists' attraction to the more coherent accounts of older people should not hide the fact that the stories we collect are constructed, sustained and altered in their passage between many minds, and through the different understandings of the young and old, women and men. To heed this warning I will trace out how understanding ekila develops over time and changes with gender and generation.

\section{Ekila and the developmental cycle}

By using experiences that are inevitable for each successive generation, such as menstruation, childbirth and killing animals, as a mnemonic focus for thought, abstract cultural concepts become tangible, meaningful and personalised. The core beliefs and practices of ekila focus on primary human experiences and the primordial symbolism of blood. This tendency is significant in an oral society where memorability is important for continuity. Ekila's striking core symbolism of menstrual blood is very memorable. Around this are clustered a series of relationships connected to the core by culturally mediated equivalences and transformations.

The existence of ekila is often first signalled to young children (as it was to me early on in research) by the food prohibitions their parents observe. Food is really fascinating to young children. The prohibitions on eating ekila animals that their parents respect as their younger siblings are born and learn to walk are not applied to them. Their mother will cook them ekila animals without eating any herself and may sometimes even go hungry. Most children notice this striking behaviour. Other times they will hear adults making 
remarks about ekila. These actions and events will only be partly understood by the child because they do not directly affect the situation, and Mbendjele cosmology and theories of procreation are unlikely to be of much interest.

Menstruation is the main event that changes all this. With her menarche a girl is suddenly referred to as ekila. This triggers her interest in ekila in a new way. In my brief experience Mbendjele girls’ first menstruation occurs at around 12 to 14 years of age. No special celebration takes place to mark it. Her mother simply explains what to do. In future, when noticing her menses, she must inform her siblings, and, if married, her husband. During this time they, like her, should not go far from camp for fear of being attacked by dangerous animals. Departures to other camps will be put off for several days.

If she does not already know, her mother or another close female relative take her to an Essiko tree to prepare the spongy side of the essiko bark into a soft material to place in the cache-sexe (gondo) and catch the menstrual blood. Etsbe bark is added as a deodoriser. She is shown how to tie her cache-sexe tightly around her womb to help squeeze out the blood and minimise the chance of it running down her legs. Doto leaves are sometimes tucked into the waist string for their perfume. During menstruation a woman changes her cache-sexe as necessary several times a day. She will go down to water to do this. Using ngongo leaves she will clean herself. She is told that the blood-filled sssiko bark and ngongo leaves must not be put into water but disposed of in dense undergrowth.

For the first time she is acutely aware of ekila by its startling appearance in her own body and its impact on her close family, hunting, and animals. Her brothers become aware of 
this as they are told not to accompany hunters or go far from camp while their sister is ekila. In consequence, adolescent boys and unmarried men (boka) often build their own lean-to. Although enjoying each other's company, they also do this to escape the restrictions on their movement caused by sleeping in the same hut as menstruating girls.

With adolescence, the differing physical experience of ekila clearly differentiates boys from girls, orientating them towards different activities, spaces and perceptions of their role in society. Girls now begin to understand how ekila limits women’s activities. They become interested in feminine power, in procreation and in cosmology as it relates to these subjects. This interest will lead to a girl's initiation into women's secret cults. In Ngoku she learns the procreative secrets of women and how to use sexuality to control men. In Yele she learns how women use their secret knowledge to ‘open the camp’ for meat, and 'to tie up' the spirits of game animals so that men may find and kill them.

A boy begins to learn more about ekila through accompanying his father to help butchering and carrying back the meat. This occurs whenever a boy shows sufficient strength and ability, often around the age of eight or nine. As I discovered when I began to accompany hunters, learning is almost entirely implicit and mostly occurs as the boy overhears hunters discussing ekila in relation to hunting and animals. Only once he realises the equivalence implied by labelling women's menstruation ekila too, may he, like the anthropologist, begin puzzling over what this means and seek clarification.

Once he begins killing game himself (the age this occurs varies greatly between individuals), he is advised on how to look after his ekila. For instance, if his mother becomes pregnant, he has to take precautions. He, like his father and other brothers who hunt, will prepare a small, 3-4cm-diameter ball of red mongole paste. Without fuss his 
father incises his pregnant mother just below the navel. The blood that flows from these fine lines is mixed into the mongole ball ( $\varepsilon s i y o$ ) of each hunter and carefully stored for use until the birth.

Whenever they go hunting, honey collecting or undertake a mystical activity, men rub the paste ball vertically down the middle of their forehead, creating a red line running from hairline to nose. To have a chance of finding game they must not rub or remove the line; the wind must take it. If the man kills, he must butcher the animal where it died and throw the breastbone, heart, liver and lungs (his ekila meat and part of the men's piko meat) into the undergrowth. An older man might also add the words 'Take it!' or 'That's yours'.

Observing hunters going out with striking red lines on their faces aroused my curiosity, as I imagine it does for youthful Mbendjele. Even more intriguing were the puzzling answers people gave to my questions: 'They are mobeku'; 'So they find food'; or 'To make sure they aim well'. Much later in fieldwork when I asked a friend out of earshot of others he explained in a whisper that there are numerous bedio spirits that consume human and animal blood voraciously.

'They are much attached to blood, and become jealous and nasty when deprived of it. They need blood to exist. That's why a menstruating woman leaves her ekila blood in the forest. These spirits eat that blood and like it more than other blood. They get used to it, and will look out for her. When her man cuts her moon, those spirits miss many meals. They get furious and very jealous of men when they realise. So they try to stop us getting food. But the forefathers found ways to avoid this. That's what the esiyo (red paste ball) is for. You don't rub it 
off. You let the wind take it to the bedio spirits. The blood will calm them, so you can find food. We leave the ekila meat for them to eat., ${ }^{, 13}$

As Mbendjele persons move through life new areas of cultural knowledge are sought and revealed through their changing experience of ekila proscriptions. Yaka cosmology becomes essential for understanding ekila practices. When young people first marry they start to become aware of ways in which procreation intertwines their ekila through menstrual taboos. But this point is most forcefully imposed on them with pregnancy. Now they must respect proscriptions against eating many frequently killed animals.

Since these prohibitions will be maintained until the child can walk there is ample time for curiosity to be aroused. Radcliffe-Brown suggested that when Andaman Islanders forbade boys and girls prized food such as turtles during puberty rites, it served to provoke them to think about why they should be excluded. Ekila practices seem to provide a similar ‘sort of moral or social education’ (1933: 276). Repeatedly being reminded not to eat desirable foods provokes curiosity and a search for answers, or at least makes someone attentive to proffered explanations. So learning that small helpless animals are often reincarnated sorcerers who ate people when human, explains why they have big ekila and must be treated carefully when killed. It is their jealousy of living people that causes them to seek to harm human foetuses and infants (the work of human ekila). But they cannot affect hunting since they are to be hunted as a punishment by God $($ Komba).

As new ekila-related practices are demanded of the maturing person, new challenges to their intuitive logic are presented. In an informal way, these practices and rules relating to 
ekila provoke questions that require learning further key areas of cultural knowledge in order to be understood. This is not explicitly taught, but requires the person to take the initiative. Natural curiosity provides the motivation. In this way, ekila again acts as a mnemonic that guides people towards finding out about more abstract knowledge and values. For instance, that adultery and promiscuity ruin a couple’s ekila implicitly values faithfulness. Through ekila practices cultural knowledge is embodied in people's lived experiences and so becomes meaningful, relevant and memorable.

Bloch (1998: 7) observed that in highly schooled societies the prominence of explicit instruction may blind us to the way much culturally transmitted knowledge is actually transferred through bodily practice and experience rather than by explicit articulation in language. This discussion of ekila has attempted to trace some of the ways in which key areas of Mbendjele cultural knowledge are first made manifest mnemonically in bodily practice before they begin to be reflected on and eventually articulated verbally. Even then their articulation is partial and often counter-intuitive. This counter-intuitive aspect seems purposeful, for it stimulates the learner to find out more. Provoking curiosity is a key pedagogic device, ensuring that learning about ekila does not encourage the development of hierarchy between people.

\section{Ekila and Egalitarian Ethics}

The developing experience of ekila sets up a series of mental puzzles whose solution requires the acquisition of other more abstract areas of cultural knowledge. This was all too clear to me as I began writing up my ekila notes. Ekila is structured 'to make you think'. Initial puzzlement, for example, over the concerns with smells leads to an increasing comprehension of ekila's rationale of smells - its causal structure. Further 
puzzlement leads into normative, moral, cosmological and political components - its participatory structure.

Ekila's implicit pedagogy establishes a process that reveals key aspects of a distinctive cosmological, political and ethical identity. In order to make sense of ekila proscriptions, such as 'do not eat Bongo antelope' an individual must think about the whole system. As Bourdieu suggested; 'an implicit pedagogy can instil a whole cosmology’ (1977: 95).

Atran described 'complex cultural categories', of which ekila seems a good example, as composed of a 'core of spontaneously learnt knowledge and a periphery of further knowledge that requires deliberate learning ... one is more stable than the other ... they are functionally related: the very existence of the periphery is made possible by the core' (1993: 67). The spontaneously learnt core of ekila is based on the inevitable maturation process and common experiences of every individual's life cycle - food, puberty, bloodletting, sex and the procreative process, and expands, with deliberate learning, to reveal gender, moral, normative and political ideologies.

Children and young people learn the core of ekila practices and beliefs - concerning ekila animals, the effect of menstruation on animals and its consequences for hunting - fairly easily, couched as they are in powerful bodily experiences and the vivid symbolism of blood. But children are unlikely to understand the relations between these core symbols and the clusters of meanings that connect with abstract social values and cultural ideologies on the periphery of ekila. Understanding this periphery builds up over time as other experiences and models are internalised. 
Core ekila practices and beliefs orientate girls and boys to focus on different tasks, eventually leading to them specialising in different, but complementary skills. As this occurs they also become aware of other areas of cultural knowledge that become relevant because they offer explanations for what they are living. As we have seen, ekila goes beyond simply encouraging and defining gendered ways of working. It connects contemporary work roles with the origin of Mbendjele society, emphasising that men and women could be economically independent. This has political consequences.

An Mbendjele woman, or man, does not depend on anyone else for direct and unrestricted access to food, nor for many of their other requirements should they wish to break away from others. As Woodburn (1982) made clear, such an absence of dependency is the necessary prerequisite for egalitarian gender relations. A person in authority can exert power over others only if he can withhold basic requirements such as food, access to resources, or marriage partners. This is not possible between Mbendjele.

The degree of personal autonomy Mbendjele enjoy could imperil communal life if it were not for other areas of cultural ideology. Ekila's emphasis on the complex balance of difference and interconnectedness between men and women counteracts this tendency to fragmentation and individualism. Mbendjele often talk about this balance in terms of ‘cutting' (moena) and ‘tying' (mokata).

Thus during Yele trances women 'tie-up' the spirits of game animals ${ }^{14}$ in order for men to be able to find them. Men 'cut' the life of the animal and butcher it. Women's cooking 'ties' the meat back into the community. Men 'cut the moon' in order for women to become pregnant. Women 'tie-up’ the man's semen to grow the foetus. Women 'cut' the 
umbilical cord at birth to separate baby and mother; the father provides the name which 'ties' the baby into society by incorporating the child into his clan. At death women are ritually concerned with cutting the spirit from the body (sending the spirit to Komba), the men with burying the body and ensuring the body is 'tied' into the earth ${ }^{15}$. These dialectics of cutting and tying negate claims to higher status by either men or women, and emphasise the vital contribution of each gender to the successful outcome of social living.

Mbendjele ideology creates interdependencies between the sexes by attributing the highly valued production of one gender to the activities of the other. Thus women grow men's children by turning semen into a foetus and men kill and butcher animals that women's mystical activities have enabled to be caught. These assumptions could be described as ideological ‘levelling mechanisms’ (Woodburn 1982) that effectively cut each gender group off from the potential status derived from the high social value of the tasks they uniquely perform, while ideologically tying them back together for successful social life to occur.

The Mbendjele do not have equivalents to our notions of politics or philosophy. There is no explicit discourse on 'equality'. Rather the implicit valuation of equality crucially underpins the cultural logic of key social concepts such as ekila, just as ekila supports the egalitarian nature of Mbendjele society. A further dimension of ekila will illustrate another way this can happen.

I described how the logic of smell is used to explain the causal structure of many ekila beliefs: Menstrual smell or the odour of sexual intercourse causes animals to flee or attack. Blood-consuming spirits are especially attracted to menstrual blood that they 
consume through the wind. The movement of smell appears to link key ekila actions with their consequences. The significance of smell in the forest, where visibility is often poor, is obvious to all Mbendjele, and thus provides a tangible connection for an early understanding of ekila.

However this logic of smell is insufficient to explain other ekila practices. So the inquisitive individual is prompted to discover other relations that serve political ends. Like numerous other hunting peoples, such as the Batek, Chewong, Penan and others in South-east Asia (Endicott 1979; Howell 1984; Needham 1967), the Mbendjele insist that an animal's carcass must not be laughed at or the hunter's ekila will be ruined. Phata explained to me that if someone mocked an animal brought back by a hunter, they would be likely to get the following response:

'Stop laughing at my animal. That animal felt great pain and suffering from my bullet. Why do you laugh at my hunting?'

If the person does not stop, the hunter will stop him from taking any meat. Komba (God) does not like people to laugh at animals, even when they are away from game. If you do, your ekila will be ruined and you'll miss and miss. You will need a mososo (herbal wash) to hunt again.’

(Phata, 65 year-old kombeti from Ibamba March 1997).

The logic of smell cannot explain why laughing at animals ruins ekila. Phata is clear: 'That animal felt great pain and suffering from my bullet.' This is a moral issue. Animals’ deaths should be respected. Mbendjele are involved in daily killing. Lethal weapons are readily at hand and most Mbendjele men know how to use them effectively. 
In this context ekila serves to define appropriate violence and control inappropriate violence so people live together peacefully.

Drawing blood in a fight is ekila. Despite the frequency of fighting, Mbendjele rarely draw blood. Formalised styles of engagement control fighting and seek to reduce the risk of spilling blood (Lewis 2002: 156-8). Murder is rare. In contrast, killing animals is justified by the belief that humans and animals are in conflict (bita) and that sorcerers are reincarnated as game for people and other predators to kill and eat. This belief also serves as a powerful sanction against killing other people for fear of being reborn as a duiker.

In addition to mockery, laughing can be caused by jealousy. Jealousy ruins ekila, but only when felt by other people or spirits, not by animals. Good hunters will prefer not to hunt, rather than be perceived as being particularly successful. This inhibits them from openly proclaiming the dependence of the group on their kills, encourages proper sharing and makes claims to status on the basis of hunting prowess unlikely. Benasongo was an exceptionally successful, but boastful hunter. His continuing success made others suspect he was a sorcerer. The women forced him into exile by collectively refusing to cook his kills (Lewis 2003).

Ekila acts to deny individuals recognition of their unique or exceptional skills. As men deny women make children, and women that men find meat, it is denied that good hunters have greater skill than other hunters. If ever I asked why a particular person was a good hunter, men would dogmatically insist that it was because he does not ruin his ekila by 'wasting it on other women'. It is not a question of hunting skill but of sexual discipline. 


\section{Ekila and proper sharing}

I have described how ekila unfolds into diverse areas of cultural practice and values. Now I wish to emphasise how ekila instills an ideology of proper sharing that is the key to the effective and safe enjoyment of forest resources and the guarantee of their continued abundance.

To emphasise ekila's sharing element: If either husband or wife inappropriately share their sexuality with others outside their marriage, both partners have their ekila ruined. By not sharing animals and meat properly among all present a hunter’s ekila may be ruined so that he is unsuccessful in future. If parents of infants eat ekila animals, it can provoke illness and even death in their children. A menstruating woman is ekila and must share her menstrual blood (also ekila) with spirits so that her male relatives continue to find food. Even laughter should be shared properly. Laughter shared between people in camp during the evening makes the forest rejoice, whereas laughing at hunted animals ruins the hunter's ekila.

Consistent with an egalitarian ethic that seeks to avoid singling out individuals for praise or condemnation, ekila provides a neutral medium for discussing success and failure. Thus difficulties in the food-quest or procreation are discussed in relation to ekila rather than to inadequacies in human skill or the environment's ability to provide. People recognise each other's skills but it is impolite to refer to them. Rather, success is talked about in terms of proper conduct in personal and mystical relationships, as defined by ekila's ideology of sharing. 
In its broadest unfolding ekila is a body of practices that regulate the Mbendjele's social and environmental relations. Once we came across a whole area of forest that was ekila. Leaf cones placed on every path leading into it warned people not to get food there or hunt, but simply to pass through. Ekila is an idiom Mbendjele use to manage the relationships that compose their total environment, which includes animals, people, spirits and the forest.

\section{Reproducing an egalitarian society}

Although ekila contributes to the mechanics of a non-explicit egalitarianism, at its most fundamental level ekila serves to organise gender roles by defining them as primordial, as bound to bodies and biological processes. Ekila establishes hunting and childbirth as prototypical activities, defining people as men and women, and weaves these roles together in a complex set of interrelationships that serve to counter the strong tendency towards autonomy and fluidity in association. The language of cutting and tying is used to elaborate this. Ekila addresses cutting in its discourse on proper sharing and keeping things apart, but simultaneously ekila ties many things together - smells, gender roles, married couples, sexual politics, cosmology, and egalitarianism as a political, moral and economic orientation.

Ekila takes advantage of the extent to which human bodies develop in fundamentally the same way to provide a framework for cultural knowledge to bind onto. It does this in diverse ways, and flexibly, enabling new ideas and associations to be incorporated if they fit into the overall framework. Ekila is an example of what Robertson describes as a 
mediating process that relates the formation of human bodies to the formation of human ideas (1996: 601).

Brunton (1989) claimed that egalitarian societies are inherently unstable owing to their inability to assure cultural continuity, to judge or condemn new innovations or to impose the reproduction of the old through institutions or authoritative individuals.

'To the extent that their egalitarianism is thoroughgoing, such cultures can be little more than heaps of randomly associated elements, whose persistence is always fortuitous. Whatever complexity may be present is not an outcome of an underlying structure connecting the elements, but rather of their number' (1989: 678). 'Unless there are at least some individuals who are recognised as having the right to evaluate the correctness of these kinds of cultural practices when they are passed on to others - i.e. individuals with authority - their persistence is fortuitous.' (1989: 679)

Of course this is true to some extent, but Brunton ignores the importance of nonlinguistic transmission in assuring cultural continuity. Ekila's basically non-linguistic nature means that it is difficult to articulate it explicitly as a coherent body of ideas. This partly accounts for the scarcity of analyses of ekila-like practices in the ethnographic literature on Pygmy people. It also makes ekila difficult to manage by 'authority'. Ekila condenses values and meanings to establish a cultural-store that ensures internal communication between generations without attributing special status or authority to individuals or institutions. It works by hidden persuasion, by provoking curiosity and stimulating each new generation to discover Mbendjele egalitarian ethics, the ideology of sharing and key aspects of their cosmology. 
Biesele (1993: 52) notes that many contemporary hunter-gatherer societies have remained oral societies because they have functioned successfully that way for so long. Cultural storage devices such as ekila, ontogenetically anchored in striking events such as menstruation, may be more enduring and stable than might be expected. In the case of ekila the diversity of different Pygmy hunter-gatherer groups - Aka, Baka, Luma, Mbendjele and Mikaya - using the same term, despite speaking different languages, suggests this. In the case of menstruation, the popularity in human societies for symbolic and practical elaborations around it attests to its enormous potency as both good to think with and good to scaffold values and gendered practices on (e.g. Testart 1986). Menstruation seems to play an astonishingly important pedagogic role in ensuring that successive generations of people discover and reinvent society for themselves, while experiencing continuity with their forebears.

\section{NOTES}

$\mathrm{PhD}$ research was supported by the Wenner-Gren Foundation, an Emslie Horniman Scholarship and the Swan Fund (1994-1997). I return regularly to the Mbendjele area. My thanks to the anonymous JRAI reviewers, L. Freeman, G. Lewis, C. Stafford, J. Woodburn, AN102 students, and audiences at the University of East London and the LSE Africa Seminar for valuable comments and criticisms.

${ }^{1}$ Groups calling such practices ekila include the Aka, Baka, Luma, Mbendjele and Mikaya. The Bongo in Southern Congo and Gabon have corresponding practices, as do the Mbuti and Efe in the Ituri, DRC.

${ }^{2}$ Ichikawa offers the most sophisticated analysis of such practices (1987). Bahuchet (1985: 443-6, 495, 524) is the only Aka ethnographer to devote attention to ekila. 


\footnotetext{
${ }^{3}$ Testart (1986) traces how blood symbolism shapes gendered work-roles from hunter-gatherers to contemporary French society. Knight takes an evolutionary perspective on menstruation to explain the emergence of human social organisation (1991). Buckley and Gottlieb’s volume (1988) provides an overview from several societies.
}

${ }^{4}$ Buckley and Gottlieb (1988:22) cite explanations for the origins of menstrual taboos originating in observations that dangerous animals attack and prey animals are repelled by humans emitting menstrual odour. However, empirical research remains inconclusive.

${ }^{5}$ For Mbendjele and Ju/'hoansi menstrual power is not caused by pollution. Rather, it marks a woman as being extra-ordinarily powerful since menstruation indicates the peak of her procreative power. Like Mbendjele women, Ju/'hoansi say that menstrual blood combines with semen to form a baby (Biesele 1993).

${ }^{6}$ If you struck prey first, but another hunter (mokobe) delivered the fatal blow, you still get the ekila meat. The mokobe will be eligible for certain cuts depending on the prey: for instance; an elephant's foreleg, or a pig's ribs.

${ }^{7}$ Like men, hunting dogs have ekila. When they attack prey, often pigs, they immobilise the animal by dislocating the hip through violently shaking a hind leg. Then the dog barks to call the men. They kill the animal. The dog eats the lungs (mulema) to maintain its ekila.

${ }^{8}$ The restrictions of this paper do not permit a complete listing of the variety of ekila animals, practices and beliefs. Here it is the dynamic nature of ekila beliefs and practices that are the primary focus of analysis.

${ }^{9}$ Sorcerers are incarnated as blue duikers (and other small helpless animals) as punishment for eating people when human. This accounts for the emphasis on avoiding the 'gundu' (belly) - the seat of sorcery. ${ }^{10}$ I am often asked to look out for peoples’ dead relatives when I return to Europe, mostly to tell them to send goods and money to their living relatives in Congo.

${ }^{11}$ The bark of Pterocarpus soyauxii has a special place in Central African ritual as the source of red colouring, Turner (1967: 66).

${ }^{12}$ In typically subversive Mbendjele style, women say that they make babies by mixing their menstrual blood with their man's semen. This undermining of each other is typical of Mbendjele gender relations (Lewis 2002: 173-197). 


\footnotetext{
${ }^{13}$ Talking publicly about edio will offend them. Misfortune will follow. This partly accounts for the difficulty in researching cosmological issues in groups or using an interpreter. My informants wished to remain anonymous.

${ }^{14}$ The verb mo.kobi.e. refers to the action of women tying up the spirits of game 'baito ba mu kobie nyama na gundu a gabo' (women 'tie-up' game with their powerful stomachs).

${ }^{15}$ Although Mbendjele make most of these distinctions, in a few cases where I have inferred them I indicate this by italics.
}

\section{REFERENCES}

Atran, S. 1993. 'Whither Ethnoscience?’ In Cognitive Aspects of Religious Symbolism, P. Boyer (ed), Cambridge: Cambridge University Press, pp. 46-70.

Bahuchet, S. 1985. Les Pygmées Aka et la Forêt Centrafricaine. Ethnologie écologique, Ethnoscience 1. Paris: SELAF/CNRS.

Biesele, M. 1993. Women like meat: the folklore and foraging ideology of the Kalahari Ju/'hoan, Johannesburg: Witwatersrand University Press.

Bird-David, N. 1990. 'The Giving Environment: Another Perspective on the Economic System of Gatherer-Hunters.' Current Anthropology 31, 189-196.

Bleek, D and L. Lloyd. 1968 (1911). Specimens of Bushman Folklore. London: George Allen. Facsimile reprint, Cape Town: Struik. 
Bloch, M. 1998. How We Think They Think. Oxford: Westview Press.

Bourdieu, P. 1977. Outline of a theory of practice. Cambridge: Cambridge University Press.

Brunton, R. 1989. 'The Cultural Instability of Egalitarian Societies.' Man, New Series, 24: 4, 637-681.

Buckley, T. and A. Gottlieb (eds). 1988. Blood Magic: The Anthropology of Menstruation. Berkeley: University of California Press

Endicott, K. 1979. Batek Negrito Religion. Oxford: Clarendon Press.

Farnell, B. 2000. 'Getting Out of Habitus: An Alternative Model of Dynamically Embodied Action.’ Journal of the Royal Anthropological Institute, 6:3, 397-418.

Fortes, M. 1981. Oedipus and Job in West African Religion. New York: Octagon.

Howell, S. 1984. Society and Cosmos. New York: Oxford University Press.

Ichikawa, M. 1987. 'Food Restrictions of the Mbuti Pygmies, Eastern Zaire.' African Study Monographs, Supplementary Issue 6: 97-121.

Knight, C. 1991. Blood Relations: Menstruation and the Origin of Culture. London: Yale University Press. 
Lewis, J. 2002. Forest hunter-gatherers and their world. PhD thesis: University of London.

--- 2003. The hunter's curse. Film.

http://clt011.lse.ac.uk:8383/steve/wgo/wgoLevel3.html

---- forthcoming. 'As well as words.' In Botha, P. and C. Knight (eds.) The Cradle of Language Volume 2: African perspectives. Oxford: Oxford University Press.

Needham, R. 1967. 'Blood, Thunder and the Mockery of Animals'. In Myth and Cosmos (ed.) J. Middleton, 271-285. New York: The Natural History Press.

Ngubane, H. 1977. Body and mind in Zulu medicine. London: Academic Press.

Radcliffe-Brown, A.R. 1933. The Andaman Islanders: a study in social anthropology. Cambridge: Cambridge University Press.

Robertson, A.F. 1996. 'The Development of Meaning: Ontogeny and Culture’. Journal of the Royal Anthropological Institute, 2 (4): 591-610.

Testart, A. 1986. Essai sur les fondements de la division sexuelle du travail chez les chasseurs-cueilleurs. Paris: Editions de l’Ecole des hautes études en science sociales.

Turner, V. 1967. Forest of Symbols. Aspects of Ndembu Ritual. London and Ithaca: Cornell University Press. 
Woodburn, J. 1982. 'Egalitarian Societies.' Man, the Journal of the Royal Anthropological Institute, 17, 431-451.

Jerome Lewis lectures in the Department of Anthropology, University College London. He has worked with hunter-gatherers and former hunter-gatherers in Central Africa since 1993.

Department of Anthropology, University College London, Gower Street, London, WC1E6BT, UK.jerome.lewis@ucl.ac.uk 